\title{
"If you thought this story sour, sweeten it with your own telling" - Cross-cultural intertextuality and a feminist poetics of rewriting in Susan Price's Ghost dance
}

\begin{abstract}
The attempts to challenge conventional gendered discourses in children's fantasy have often resulted in feminist rewritings of earlier stories. Ghost dance (1994) by the English author Susan Price is a novel that reflects a specific feminist poetics of rewriting: metafictional passages highlight the constructedness of the narrative and at the end readers are invited to tell their own versions of the story. Moreover, the rewriting freely combines and recontextualises elements from different source texts and reformulates them to create a narrative that challenges conventional discourses of gender. While this poetics has an appeal from a feminist perspective, the play with cross-cultural intertexts and gender becomes more complex when the novel is examined in a postcolonialist framework in relation to ethnicity and the issue of cultural appropriation. Ghost dance is situated in a setting that has a real-world equivalent (Russia), involves characters that are identified with names of realworld ethnic groups (Lapps (Sámi), Russian), and mixes elements from Russian wonder tales, Nordic mythology and an Ojibwe legend. The novel does not aim at historical accuracy in its representations nor is it a direct retelling of any of the pre-texts but combines motifs, themes, names, characters and settings freely from each source. In this textual melting pot, the protagonist Shingebiss is, on one level, a revision of the witch Baba Yaga, but also described as a Lappish shaman with an Ojibwe name. To rewrite gendered discourses, certain elements from the pretexts are chosen and others left out - the question is, then, what effects does this recontextualisation have on the representation of ethnicity? Or, are the feminist rewriting strategies actually a form of cultural appropriation?
\end{abstract}

Keywords: children's fantasy, gender, ethnicity, cross-cultural intertextuality, Susan Price 
Susan Price's Ghost dance (1994, henceforth Gd) begins with a brief introduction of the narrator, a learned cat that walks around an oak tree by a lake somewhere far away - when the cat walks one way, it sings songs, as it walks the other, it tells stories. After this, the cat's story begins: "I tell (says the cat) of the Northlands, where, in the long, dark winter, the white snow falls out of the black, black sky. Soft, silent it falls through the branches of the pines and birch, and mounts, thin flake on thin flake, until the snow lies ten cold feet deep, and the silence is frozen to the darkness" $(G d, 1)$. The fairy tale beginning formula which introduces the setting - often a distant place - here situates the story in the Northlands which from Price's British perspective may seem distant but is not that far away from all of us. Although the Czardom in the novel is never explicitly referred to as Russia, those readers who know anything about the country's climate, location and titles of former rulers will be able to recognise the clues. The story-world shares several other features with the real world of some obscure past: there are countries called England and Denmark outside the Czardom, and reindeer people, or Lappish people living in the Northern parts of the Czardom. While "Lappish" as a name of an ethnic group referring to the Sámi people is now considered a derogatory term, the terms "Lappish" and "Lapps" were earlier commonly used of Sámi people and appear both in studies of shamanism (see Eliade 1972, 15) and Nordic mythology (see Ellis Davidson 1973, 30-31; Simpson 1973, 170-171).

Apart from the names of the countries and the peoples and the description of the climate of the Northlands, historical accuracy is not the aim of the novel or its predecessors, The ghost drum (1987) and Ghost song (1992) - the first of which was awarded the CILIP Carnegie Medal in the UK in 1987. The ghost world novels form a loose trilogy: although the novels are situated in the same fictional world and share some characters, the plot-lines do not form a chronological continuum. Ghost dance, subtitled The czar's black angel, is an allegory of colonialism and its environmental and cultural effects; it is a story about a transgender shaman girl who sets out to spell the Czar, God on Earth, to stop the destruction of the Northlands and the people living there. Unlike several feminist fairy tale rewritings, the novel is not a retelling or novelization of any specific tale but a montage that combines and reframes formulas, motifs, settings, names and characters from the Russian wonder tale tradition, Nordic mythology, an Ojibwe legend and representations of Northern shamanism in anthropological accounts and mythological studies. The common factor of the source texts is that they are all associated with the North: Russia, Scandinavia, 
and Canada or the Northern parts of the United States. In this paper, I will argue that while the strategy of freely combining and recontextualising earlier stories or parts of them may successfully function as a feminist poetics of rewriting, in terms of ethnicity the cross-cultural intertextuality is a more problematic issue.

\title{
A feminist poetics: framing the narrative as a literary fairy tale
}

By a feminist poetics of rewriting I am here referring to textual strategies such as metafiction, intertextuality and irony that are applied to rewrite, challenge or question conventional gendered discourses in earlier texts and traditions. The feminist poetics in Ghost dance is Western in its notions of literary texts and use of source texts: all kinds of elements (unless protected by copyright) can be combined freely to suit the author's purposes. The poetics is explicitly addressed in the novel in the use of metafictional frames that highlight the text as a rewritten, literary fairy tale.

In Ghost dance, the framing narrative of a scholarly cat telling the story is clearly a reworking of Alexandr Pushkin's prologue to his fairy tale poem "Ruslan and Ludmila" (1828), which introduces a learned cat as the source of the stories:

\begin{abstract}
A green oak stands by the shores of a bay. Around the oak is a golden chain, and day and night a learned cat walks round and round on the chain. As he walks to the right, he sings a song; as he walks to the left, he tells a story.... And there I sat, drinking mead. I saw the green oak by the sea, and sat beneath it as the learned cat told me his stories. Some of these I remember, and I will tell them now to the world. (In Bayley 1978, 13.)
\end{abstract}

This passage is reformulated in Price's novel as follows:

In a place far distant from where you are now grows an oak tree by a lake. Round the oak's trunk is a chain of golden links. Tethered to the chain is a learned cat, and this most learned of all cats walks round and round the tree continually. As it walks one way, it sings songs. As it walks the other, it tells stories. This is one of the stories the cat tells. $(G d, 1$.

The passage is not an exact citation (which might be due to the translation of Pushkin; this is Jane Dalley's 1978 prose translation), but it is very close to the original. To introduce the cat as a narrator in Pushkin and Price serves as a metafictional device to remind readers that what 
follows is a piece of fiction, or, more precisely, a fairy tale. Employing a cat as a narrator has a distancing effect - both distancing the readers from the story and distancing the external narrator and the author from the source cultures of the stories. As literary writers, both Pushkin and Price are cultural outsiders to the oral traditions they are borrowing from. In relation to Pushkin's fairy tales, John Bayley $(1978,11)$ suggests that Pushkin made no claims to authenticity and cared little what his sources were "provided that he could adapt them to his purpose", while in her study of Pushkin's "Tale of the tzar Saltan", Janina Orlov $(2005,152-154)$ concludes on a more positive note by arguing that Pushkin deliberately plays with generic conventions and creates his own "poetic mythology". I would suggest that the same concerns Price who combines the Russian influences freely with elements from other traditions. Although adapting folklore material to new purposes in literary works is a common phenomenon, the "Ruslan and Ludmila" intertext in Price explicitly highlights the fact that the author, as her literary predecessor, Pushkin, is creating her own literary universe which is inspired by folklore but also removed from it. What is at stake is not authenticity but literary concerns about themes and aesthetic visions.

This kind of poetics is emphasised at the end of Ghost dance when readers are invited to retell or rewrite it themselves:

If you thought [this story] tasty, then serve it to others.

If you thought it sour, sweeten it with your own telling.

But whether you liked it, or liked it not, let it make its own way back to me, riding on another's tongue. $(G d, 217$.)

Circulation and reinterpretation of tales is here seen as the common process of story telling, and while this might seem a feature typical of oral story telling, it is, in fact, a central idea of Western literary aesthetics. The poetics and, at the same time, the politics of rewriting are summarised in the cat's notion: "If you thought this story sour, sweeten it with your own telling". Reinterpretation or deconstruction and reconstruction of tales are viewed both necessary and acceptable - in Price's text this is partly done for feminist purposes. It does not matter where the stories come from - and, in terms of cultural appropriation, this is the key issue. As Deborah Root $(1996,19)$ notes, "within Western aesthetics other cultural traditions have been assigned the role of artistic resource, to be harvested pretty much at the pleasure of the colonizers". My aim here is not to deem this kind of use of resources as morally or politically unacceptable but to consider the implications of cross-cultural intertextuality on the representation of gendered and ethnic identities in the novel. 


\section{Appealing others: ways to rethink gendered discourses}

In terms of gendered discourses, the strategy of rewriting any stories as pieces of fiction is appealing - there are innumerable stories that, from the feminist perspective, might be sweetened. Sometimes to be able to rethink gendered structures in one's own culture it may seem a good choice to look for sources in other cultures. Ghost dance challenges conventional ideas and discourses of gender through the characters of the witch and the shaman - each symbolic character in Price's text is inspired by non-English traditions and texts.

First, the novel is a feminist reworking of Russian wonder tales, constructing the witch, Baba Yaga, as a woman of power. In Russian wonder tales Baba Yaga is sometimes a cannibalistic ogre, elsewhere a helper of a brave heroine or hero, but not the sympathetic mentor and foster-mother she is in Price's text. In Ghost dance, Baba Yaga is replaced by a community of female witches and shamans that live in huts on animal legs - even in characters' recollections of stories they have heard. The female protagonist in the novel, Shingebiss, is a young witch in training, guided by her foster grandmother. As a revised Baba Yaga, Shingebiss reflects the radical feminist rewritings of witches that turn the stock characters into representations of more complex persons who have feelings and histories and view witchcraft as matrilineally inherited. The radical feminist discourse of witches is, according to Diane Purkiss (1997, 21-22), popular among both contemporary wiccas and feminist fiction writers and also, as John Stephens (2003) writes, in contemporary children's fantasy. In this discourse, old and ugly witches are replaced by wise sages, healers or, in Ghost dance, shamans. Shingebiss and her shaman grandmother are sympathetic outsiders whose way of life - which is, significantly, in harmony with nature - offers an alternative to the fictional totalitarian Russian czardom in the storyworld, the czardom representing any kind of totalitarian regime. The main plot in the novel concerns Shingebiss' quest to spell the Czar and stop the destruction of the land and the indigenous people - the new Baba Yaga in Ghost dance is the compassionate witch or woman who in radical feminist and later eco-feminist discourses is the preserver of life and nature. Thus she also serves as an environmentalist character that challenges the colonialist practices of capitalist - in Ghost dance also patriarchal - societies.

Second, turning the fairy tale witches into shamans and borrowing from anthropological accounts of shamanism has appeal from a queer theoretical perspective. In Judith Halberstam's $(2005,6)$ framework 
of queer time and space "queer" refers to "nonnormative logics and organizations of community, sexual identity, embodiment, and activity in space and time" - the queer organizations thus challenge conventional ideas of gender and sexuality. As characters who live outside ordinary people's organizations of time and space the shamans fit into Halberstam's notions of queer - they live in houses that move, live for 300 years, have their own knowledge system and community and they do not reproduce but adopt children. Moreover, queer time and space is also reflected in the shamanic ability to cross and blend boundaries between worlds and identities. As an example of this, the transgender shaman occurs frequently in anthropological accounts of shamanic traditions - among others, Barbara Tedlock $(2005,250)$ mentions the widespread phenomena of shamanic "gender switching, bending, blending or reversing". In Ghost dance Shingebiss is a reflection of these traditions.

Shingebiss' gendered appearance is addressed explicitly right at the beginning of the novel when she is first introduced:

With upraised wings [the gyrfalcon] dropped from the sky into the snow, and turned into - what? Too small for a man. A boy? [...] A lad - or a girl. A girl, or a lad, who had dropped out of the tree - or out of the sky. A lad, or a girl, alone, so far from any camp or settlement - and dressed, in this cold and darkness, as if for a stroll on a summer evening. [...] The stranger came closer and, in the light reflected from the snow, they could see the face of their own people. But it could have been the face of a pretty boy or a handsome girl. $(G d, 3-5$.)

In this scene, focalised through a group of Lappish hunters, the initial uncertainty of what the bird has turned into and the repeated hesitation between interpreting "the figure" as a lad or a girl highlights Shingebiss' exceptionality from the perspective of the hunters. Whereas the hunters recognise Shingebiss' ethnicity - she is "one of their own people" - they cannot decide on her gender, for her face could be that of "a pretty boy or a handsome girl"; a feminine boy or a masculine girl. Shingebiss' gender remains a mystery also to readers until the following scene where her grandmother refers to her as "my little daughter" $(G d, 11)$. Later when she is travelling far from home among people from different ethnic groups she is interpreted as a boy because she is cross-dressing, or wearing the typical shaman clothing, and carries weapons with her. The ultimate form of portraying a masculine identity occurs at the end when Shingebiss apparently changes also her sex when she becomes the First Shaman, Loki - although this is uncertain, because in Nordic mythology Loki 
himself is a god that can change his sex. As a transgender character Shingebiss challenges the fixed, conventional notions of femininity and masculinity - she is an example that it is possible to blend the boundaries of gender and the notions of normative behaviour and ways of life.

\section{Representing ethnicity through cross-cultural intertextuality}

In terms of gender, the witch-shamans in Ghost dance are deviants who represent alternative ways of life and critique of society and thus reflect feminist and queer discourses. However, the issue becomes more challenging when the otherness is considered in terms of ethnicity; Shingebiss as a Lappish shaman with an Ojibwe name. I will here briefly comment on some of the problems with borrowing elements from Nordic myths and from the Ojibwe story of Shingebiss.

First, the term Lappish and its associations with witchery or shamanism seem to have entered Price's texts from the Nordic myths and legends that are among her sources. Because of her reindeerhide clothes characters from other ethnic groups view Shingebiss as "a Lappish prince" or a witch $(G d, 71)$ and a male witch as such: "I've heard tell all you Lapps are witches. Are you a witch, son? Shingebiss smiled, and nodded" $(G d, 74)$. Shingebiss' nod here is an affirmation of her status as a witch, but it is implicitly also an affirmation of her maleness and her ethnicity. In the novel, the views of Lappish witches are shown to be outsiders' views and, as such, partly made up. The narrator tells that one traveller's "story" of Shingebiss "spread, up and down the road" $(G d, 71)$ - readers know Shingebiss' true narrative and thus they also know that the traveller's account is false. Yet, the text plays with the old stereotype of Lappish witches, common in Nordic myths and legends. In the myths, as well as here, the witches are represented as others both because of their magic skills and their (perceived) race and ethnicity. The problem is that although the characters here make up stories of Shingebiss, she herself confirms the stereotype because she is a Lappish witch. Furthermore, while the novel shows how cultural others are created in stereotypical discourses, the cultural others remain others - very little of the story is told from Shingebiss' perspective.

Second, the term used of the reindeer people and the witches is Lappish, but it seems to be appropriated as a sort of general reference to any group of Northern hunter-gatherers rather than a specific ethnic group of people - an indication of this is Shingebiss' shaman clothing that combines typical features of shaman costumes from several ethnic groups. The main function of representing the shamans 
as indigenous people is to portray a group that is ethnically and culturally different from the imperialist oppressors. After all, the title of Ghost dance may not refer only to visits to the land of the dead in Siberian shamanic traditions (see Eliade 1972, 311), but also connote the nineteenth-century pan-Indian spiritual and prophetic resistance movement (see, for instance, Smoak 2006, 1-3), particularly because Shingebiss' name comes from an Ojibwe legend.

The hybridisation of these different groups is based on their alleged similarities - they are indigenous peoples who live in the Northern parts of the world and whose spiritual systems involve shamanic features. As indigenous groups, they are also connected with ideas of anti-imperialism and environmentalism - as Clare Bradford (2007, 75) notes in her study of postcolonial texts for children, "notions of the indigenous person as "natural" ecologist abound in children's texts". These notions are also present in Ghost dance and they certainly have appeal from the radical feminist or eco-feminist perspectives - the novel sympathises with a character that tries to prevent ecological and cultural destruction and parallels the notions of a woman and an indigenous person as "natural" ecologists. While useful for the novel's argument for environmentalism, the hybridisation erases the differences between the specific groups of people who may or may not share any of these features. By situating the story in a distant, fantastic past, the novel also draws attention away from contemporary issues that the real-world indigenous groups of people face - the limitation of the novel as an allegory of colonialism is that it can make a general argument about the effects of colonialism but cannot comment on any specific real-life situation.

Apart from the problematic representation of ethnicity that circulates stereotypes from earlier stories even though partly exposing them as stereotypes, another question concerns cultural appropriation and authority - whose stories are these and who has the right to tell them? I will here address the use of the Ojibwe legend because Ojibwe reviewers have expressed their concerns about outsiders telling their stories - also the story of Shingebiss. In an early published version of the legend that appeared in Henry R. Schoolcraft's Hiawatha and other oral legends, mythologic and allegoric, of the North American indians (1856) the theme of the tale of the hunter-duck Shingebiss is expressed in its subtitle "An allegory of self-reliance". The story involves a brave duck who is not beaten by Kabebonicca (the personication of the North West winds) during the winter. Ghost dance reflects this theme but Price's retelling changes the gender of the protagonist and modifies the ending: Shingebiss' 
perseverance does not lead to positive outcomes because she cannot save the Northlands and she herself chooses to stay in the land of the dead. The new ending makes sense in an eco-feminist framework: an individual cannot save the world alone, instead of self-reliance one needs to rely on community.

What Price is rewriting, however, is another rewritten story by an author who is an outsider to the Ojibwe culture. Although in the preface to his collection Schoolcraft (1856, vii) suggests that the tales are "always true to the Indian manners and customs, opinions and theories", he also includes a long list of the "necessary" corrections that were made to obtain the "true spirit and meaning" of the tales. While Price changes Schoolcraft's "true meaning of the tale", it is ironic that, according to the Ojibwe critics Lois Beardslee (2007) and Barbara Potter (2007), Schoolcraft's theme is not the theme of their version of the story in the first place. Their story is not about self-reliance but about a friendly game between Shingebiss and the North Wind. Beardslee $(2007,408)$ comments that "Schoolcraft remains an unshakable, unquestionable source into the present among many non-Indian readers and 'scholars' $[. .$.$] While the information$ recorded is invaluable, it should be put into the context of an era of conquest during which Native Americans were depicted as childish and incapable of managing the resources of their territories within the scope imagined by the conquerors". Price does not represent Shingebiss as childish and incapable - quite the contrary - but her version is, again, an outsider's version of the story. The legend of Shingebiss is here appropriated for feminist and environmentalist purposes. Whatever meanings the Ojibwe themselves associate with their story are not considered relevant. The Ojibwe voices are silenced in the sense that, according to the kind of feminist poetics cited above, what matters is the artistic vision of the author who borrows stories by others to weave her own, new literary creation.

\section{Questioning colonialist discourses}

Although Price is freely borrowing and rewriting stories from several other cultures and traditions, the novel cannot be labelled simply as a form of cultural appropriation, or a text ignorant of the effects of colonialism. Ghost dance explicitly questions colonialist discourses and stereotypical representations by addressing colonial power and the way it works through language and discourse. The novel as a whole addresses the ways in which words and power are linked and how words can be used to manipulate others, whether they are lies, 
spells or mere play. This play is sometimes self-conscious and ironic (as in the cat narrator's use), sometimes serious and tragic (as in the Czar's use) and other times necessary for purposes that are seen as morally acceptable (as in Shingebiss' magic use of words). The novel also plays with multiple focalisation which allows different perspectives on Shingebiss. In the above examples involving other characters' notions of Lappish witches, the narrative shows how stereotypes about the Lappish people develop, as stories that "spread, up and down the road". The novel shows that the truth is not what is at stake but who is in the position to define the truth - a telling example of this is the Czar who manipulates reality by creating and repeating discourses that are false but become to be perceived as true because of his social status. The paranoid Czar's worldview is shown to be distorted, yet his gaze can be characterized as what David Harvey $(1996,284)$ describes as the Western "imperial gaze" that maps "the world according to its own needs, wants and desires". In Ghost dance, the Czar's imperial gaze defines the truth because God on Earth is infallible.

In a scene where Shingebiss first appears to him, the Czar creates his own interpretation of her according to his own logics and categorisation systems. Because the readers know that Shingebiss is a human, a Lappish shaman girl, the passages where the Czar is the focaliser are ironic and his view is framed as a distorted one. The Czar first sees "a creature" or "a ghost" with an "unearthly face" that "could belong only to a goblin or some other uncanny thing" $(G d, 106-107)$, but later Shingebiss' inhumanity is not only associated with her ghostlike appearance but also with her ethnic otherness: "the black hair and dark skin supposed to be found in demons" ( $G d$, 108). The Czar finally decides that the inhuman creature is "a Black Angel", a messenger sent to God on Earth by God in Heaven (Gd, 109). Afterwards the Czar uses Shingebiss to convince people that he is favoured by God and all the images of angels in churches are replaced by images of Shingebiss to demonstrate that the Czar's companion is truly a one from heaven. Here and in similar passages in the novel, the text exposes the ways colonialist discourses operate: the stories that rulers tell to others are not necessarily true but those in power can turn their ways of interpreting the world into regulations, laws, and forms of knowledge. In this context it is ironic that while the text demonstrates colonialist discourses at work, the novel itself is based on source texts that are authored by people who are outsiders to the cultures whose stories they tell. 


\section{"You cannot change one thing alone" - challenges of rewriting}

In terms of gender, the feminist and queer representations of the wise witch and the shaman as outsiders who blend and cross boundaries have radical potential, but in relation to ethnicity the characters are more problematic. Hybridizing different ethnic traditions from Northern Eurasia as well as from North America under the amalgam label of "Lappish" can be seen as a form of cultural appropriation. Even though the shamans are represented in positive terms, they remain as cultural and ethnic others in the novel and they also reflect the stereotypical discourse of indigenous groups as hunter-gatherers that are inherently close to nature. Nevertheless, the novel is also an allegory of colonialism that exposes and criticises the ways these groups of people are represented and treated. These contradictions bring forth the multivoicedness of the novel and therefore it would be pointless to label it simply feminist, Anglo-centric, or something else - the complexity, the different voices and discourses reflected in the text, is what should be recognised. Furthermore, the different voices and discourses are not separate from each other but connected in several ways because gender, ethnicity and other aspects of identity are intertwined. Rewriting one aspect will affect the others. In this respect, the challenges of rewriting are summarised excellently by Shingebiss' grandmother who explains the difficulty of trying to bring out any type of change: "You cannot change one thing alone; you will always change many things, and you cannot tell what might become of that - it may be worse than what you tried to cure" (Gd, 16). The one who decides whether the rewriting is for better or for worse is, of course, the reader.

Biographical information: Sanna Lehtonen is a PhD candidate at the University of Jyväskylä, Finland and at Macquarie University, Australia, working on her dissertation on invisibility, magic changes in age and girlhood in contemporary British children's fantasy. Contact: sanlehto@jyu.fi

\section{Bibliography}

Bayley, John. Pushkin's fairy tales. Translated by Jane Dalley. London: Barrie \& Jenkins, 1978.

Beardslee, Lois. "Review of Shingebiss: an Ojibwe legend (by Nancy Van Laan)". In A broken flute: the native experience in books for children edited by

Doris Seale and Beverly Slapin. Lanham: AltaMira Press, 2007, pp. 408-409. 
Bradford, Clare. Unsettling narratives: postcolonial readings of children's literature. Waterloo: Wilfrid Laurier UP, 2007.

Eliade, Mircea. Shamanism: archaic techniques of ecstasy. Princeton: Princeton UP, 1972.

Ellis Davidson, H. R. "Hostile magic in the Icelandic sagas". In The witch figure edited by Venetia Newall. London: Routledge \& Kegan Paul, 1973, pp. 20-41.

Halberstam, Judith. In a queer time and place: transgender bodies, subcultural lives. New York: New York UP, 2005.

Harvey, David. Justice, nature and the geography of difference. Malden: Blackwell, 1996.

Potter, Barbara. "Review of Shingebiss: an Ojibwe legend (by Nancy Van Laan)". In A broken flute: the native experience in books for children edited by Doris Seale and Beverly Slapin. Lanham: AltaMira Press, 2007, pp. 408.

Orlov, Janina. Texten som kalejdoskop: en läsning av A. S. Pusjkins "Sagan om tsar Saltan". Åbo: Åbo Akademis Förlag, 2005.

Price, Susan. Ghost dance: the czar's black angel. Paperback edition. Originally published in 1994. London: Faber \& Faber, 1995.

Purkiss, Diane. The witch in history: early modern and twentieth-century representations. London: Routledge, 1996.

Root, Deborah. Cannibal culture: art, appropriation, and the commodification of difference. Boulder: Westview Press, 1996.

Schoolcraft, Henry R. Hiawatha, and other oral legends, mythologic and allegoric, of the north american indians. Philadelphia: J. B. Lippincott \& Co, 1856.

Simpson, Jacqueline. "Olaf Tryggvason versus the powers of darkness". In The witch figure edited by Venetia Newall. London: Routledge \& Kegan Paul, 1973, pp. 165-187.

Smoak, Gregory. Ghost dances and identity: prophetic religion and American Indian ethnogenesis in the nineteenth century. Ewing: University of California Press, 2006.

Stephens, John. "Witch-figures in recent children's fiction: the subaltern and the subversive". In The presence of the past in children's literature edited by Ann Lawson Lucas. Westport: Praeger, 2003, pp. 195-202.

Tedlock, Barbara. The woman in the shaman's body: reclaiming the feminine in religion and medicine. New York: Bantam Dell, 2005. 